\title{
Partitioning of space and food resources by three fish of the genus Diplodus (Sparidae) in a Mediterranean rocky infralittoral ecosystem
}

\author{
Enric Sala ${ }^{1, *}$, Enric Ballesteros ${ }^{2}$ \\ 'Departament d'Ecologia, Facultat de Biologia, Universitat de Barcelona, Diagonal 645, E-08028 Barcelona, Spain \\ ${ }^{2}$ Centre d'Estudis Avançats (CSIC), Camí de Sta. Bàrbara s/n, E-17300 Blanes, Spain
}

\begin{abstract}
White sea bream Diplodus sargus, two-banded sea bream D. vulgaris and sharpsnout sea bream $D$. puntazzo coexist in Mediterranean infralittoral rocky habitats. Diets of the 3 species were quantitatively analysed, and the relative abundance of algae found in stomach contents was compared with the abundance of algae in the different habitats. These results were compared with observational studies on distribution and feeding use of the habitats. The results suggest that there was marked resource partitioning between the 3 species of Diplodus in the rocky infralittoral. $D$. sargus mainly exploited the surge zone, while $D$. puntazzo and $D$. vulgaris preferentially exploited deeper waters. Diet analysis suggested a strong feeding niche overlap between $D$. sargus and $D$. vulgaris, although they fed in different habitats, except small individuals (total length $<13 \mathrm{~cm}$ ) of both species, which shared the same resources. $D$. vulgaris and $D$. puntazzo showed strong habitat overlap, although they exploited different food resources. D. sargus and D. puntazzo showed low spatial and feeding-niche overlap. Habitat partitioning appeared to be as important as food partitioning in structuring Diplodus assemblages.
\end{abstract}

KEY WORDS: Resource partitioning · Littoral fish - Infralittoral habitats · Diplodus - Mediterranean

\section{INTRODUCTION}

The coexistence of similar species within the same ecosystem may occur owing to different resource use. Resource partitioning includes food, habitat and/or time segregation (e.g. Pianka 1973, Schoener 1974), and has been extensively documented among fishes in temperate rocky reefs (e.g. Love \& Ebeling 1978 , Hixon 1980, Larson 1980, Yoshiyama 1980. Hallacher \& Roberts 1985, Ebeling \& Laur 1986, Holbrook \& Schmitt 1986). Food segregation seems to play a more important role than habitat or temporal separations within many fish assemblages (Ross 1986). Resource partitioning in fish has received little attention in the Mediterranean (Macpherson 1981, Rosecchi 1985. Harmelin-Vivien et al. 1989), and few studies have

- Present address: Scripps Institution of Oceanography, University of California at San Diego, La Jolla, California 92093-0201, USA.E-mail: esala@coast.ucsd.edu been carried out in the rocky infralittoral dealing exclusively with small-sized fishes (Zander 1982, Macpherson 1994).

In NW Mediterranean waters, several species of Sparidae, mainly of the genus Diplodus, dominate fish assemblages in shallow rocky infralittoral habitats. The fishes Diplodus sargus (L.), Diplodus vulgaris E.G. Saint-Hilaire and Diplodus puntazzo (Cetti) are found in the rocky infralittoral. Both $D$. sargus and D. vulgaris contribute greatly to the total fish abundance (up to $56 \%$; García-Rubies 1997). Because the 3 species of Diplodus are (1) taxonomically related, (2) necto-benthic species (sensu Harmelin 1987), (3) markedly benthophagous (Rosecchi 1985, Bell \& Harmelin-Vivien 1983, Sala 1996), and (4) usually found within a small bathymetric range (Garcia-Rubies 1997), one might presume they are potential competitors for space and food resources.

Fish of the genus Diplodus are omnivorous (Joubert \& Hanekom 1980, Coetzee 1986, Mann \& Buxton 1992), 
and the amount of algae found in the stomachs of fishes from the 3 species may be considerable (Sala 1996). Regardless of whether algal consumption is voluntary or the digestion of plant material is low (Joubert \& Hanekom 1980), Diplodus species ingest a considerable amount of algae when foraging on benthic communities (Sala 1996). Algal communities show marked zonation patterns in the Mediterranean (Feldmann 1937. Ballesteros 1992), and each community is found within a relatively narrow range of environmental conditions (chiefly light and water motion). Since some algal species are restricted to or grow preferentially in certain communities, they may be good indicators of the habitat in which fish species feed.

In this study we examined patterns of habitat and food utilization shown by the 3 species of Sparidae mentioned above, which are common inhabitants of rocky infralittoral bottoms of the Medes Islands Marine Reserve (NW Mediterranean). We analysed the diets of the 3 species, and compared the abundance of algae in stomach contents with the abundance of algae in the field. We also recorded the distribution and habitat use of these fishes, and compared the results obtained from the assessment of resource partitioning made by stomach content analysis.

\section{STUDY SITE AND SPECIES}

The study was carried out in the Medes Islands Marine Reserve, in NE Spain. The Marine Reserve, where fishing is prohibited, is located $1 \mathrm{~km}$ offshore opposite the town of L'Estartit $\left(42^{\circ} 16^{\prime} \mathrm{N}, 03^{\circ} 13^{\prime} \mathrm{E}\right)$, has an area of 93 ha, and encompasses a group of a few small islands (surface area less than $20 \mathrm{ha}$ ).

Sampling sites were characterized. by bottoms of large limestone boulders, with a profusion of holes and crevices that provide refuge for fishes. At these sites, rocky substrata are covered by numerous species of alga and high densities of small invertebrates (both sessile and mobile; Ros et al. 1984).

The white sea bream Diplodus sargus is abundant in the Mediterranean (Tortonese 1975), occurring also along all the coast of Africa. It inhabits rocky bottoms and Posidonia oceanica beds, from the surface to a depth of $50 \mathrm{~m}$ (Corbera et al. 1996). In common with most Sparidae, $D$. sargus is very active, and frequents the surge zone, primarily at dawn. The two-banded sea bream Diplodus vulgaris is present throughout the Mediterranean basin (Tortonese 1975), on the Atlantic coast of the Iberian Peninsula, and on the West African coast down to Angola (De La Paz 1975). D. vulgaris is abundant over infralittoral rocky bottoms (from the surface to $30 \mathrm{~m}$ ) but often forms schools of up to 100 individuals which remain at a fixed position in the water column (Corbera et al. 1996). The sharpsnout sea bream Diplodus puntazzo is frequent throughout the Mediterranean, occurring also in the tropical Atlantic and off the north coast of Spain (Bauchot \& Pras 1980). Generally a solitary fish, $D$. puntazzo frequents rocky bottoms down to $50 \mathrm{~m}$.

\section{METHODS}

Five distinct habitats, which together occupy almost all the substrate from the surface to $-15 \mathrm{~m}$, and where fishes have always been seen foraging, were investigated (Fig. 1). These were: (1) surge zone (hereafter referred to as SZ), (2) shallow vertical walls (SW), (3) photophilic plain (PP), (4) hemisciaphilic plain (HP), and (5) sciaphilic walls ( $\mathrm{ScW}$ ); their characteristics are summarized in Table 1.

Fish distribution was determined by visual census using the stationary point method (Harmelin-Vivien et al. 1985). The observer remained stationary on the bottom at a random location and recorded the number and sizes of all fishes of the 3 species in a radius of $7 \mathrm{~m}$,

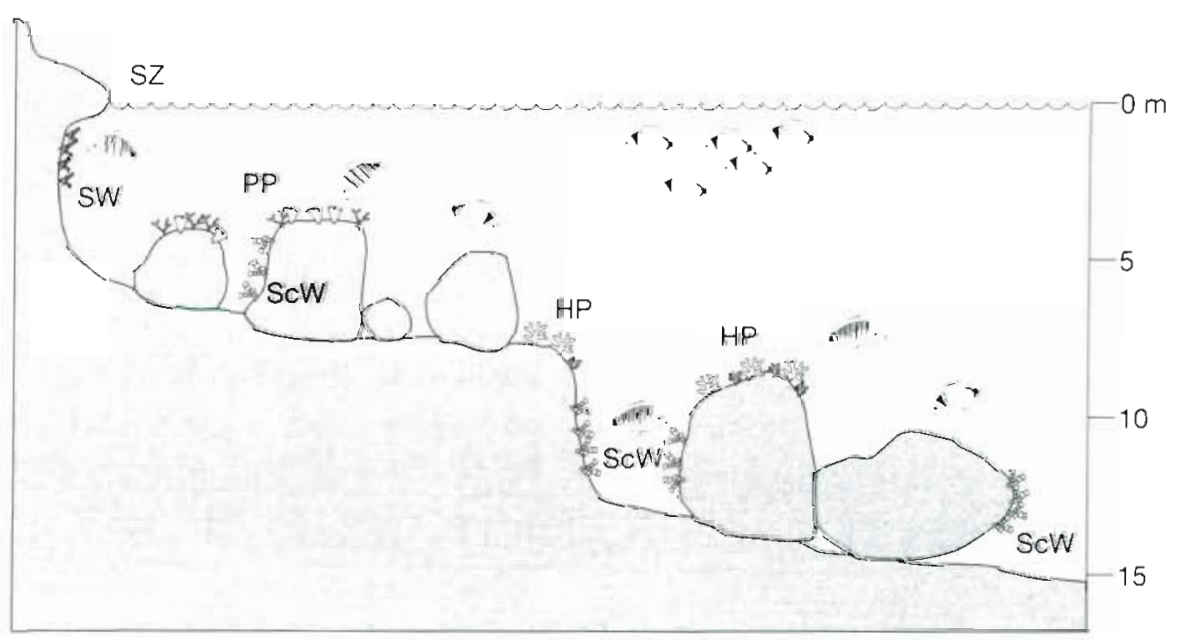

Fig. 1. Schematical representation of the Medes Islands rocky infralittoral habitats. SZ: surge zone; SW: shallow walls; PP: photophilic plain; HP: hemisciaphilic plain; ScW: sciaphilic walls. See Table 1 for a description of habitat characteristics 
Table 1. Characteristics of habitats investigated in this study

\begin{tabular}{|lll|}
\hline Habitat & Depth interval (m) & Habitat characteristics \\
\hline Surge zone (SZ) & $+0.5,-0.5$ & $\begin{array}{l}\text { Wave-splashed zone, mussel Mytilus galloprovinciale beds, belt of brown } \\
\text { alga Cystoseira mediterranea, and rim of the Corallinaceae Lithophyllum } \\
\text { lichenoides, with high microspatial complexity } \\
\text { Vertical walls with dominance of small red algae (community of Plocamium } \\
\text { Cartilagineum) and barnacles (Balanus perforatus); low spatial complexity }\end{array}$ \\
Photophilic plain (PP) & $-0.5,-2.0$ & $\begin{array}{l}\text { Plain or upper side of big boulders with dominance of photophilic algae } \\
\text { (Dictyota fasciola, Padina pavonica, Halopteris scoparia, Corallina elongata) } \\
\text { Plain or upper side of deeper big boulders with dominance of hemisciaphilic } \\
\text { algae (Codum vermilara, Dictyota dichotoma, Rhodymenia ardissonei, } \\
\text { Peyssonnelia spp.) } \\
\text { Vertical walls, deep or in the north-oriented sides of shallow big boulders, } \\
\text { with dominance of sciaphilic algae (Flabella petiolata, Halimeda tuna, } \\
\text { Peyssonnelia sp. plur.) and suspension-feeders (sponges and soft corals) }\end{array}$ \\
\hline
\end{tabular}

within the first minute. Twenty stationary point replicates were carried out for each of 3 depth-defined zones: surge zone (between $+0.5 \mathrm{~m}$ and $-0.5 \mathrm{~m}$ ), shallow zone between $-2 \mathrm{~m}$ and $-7 \mathrm{~m}$; including $\mathrm{SW}$ and PP), and deep zone (between $-9 \mathrm{~m}$ and $-15 \mathrm{~m}$; including $\mathrm{HP}$ and ScW) in summer 1996. Individual sizes were recorded in 3 discrete classes. These classes encompassed one-third of the maximum total length of each species recorded in the literature (Corbera et al. 1996). Therefore, size classes were (total length): small $(<13 \mathrm{~cm})$, medium $(13-26 \mathrm{~cm})$, and large $(>26 \mathrm{~cm})$. The determination of fish size near the limits of size classes implied a certain degree of subjectivity, especially when fish were several meters away from the observers. Thus, the inclusion of individuals into size classes was subjected to unknown error. To test differences in density between habitats, individual 1-way ANOVAs were performed for each fish species. When the analysis of variance showed significant differences, a Tukey HSD test was used.

In order to determine habitat use, feeding was observed in summer 1996 by SCUBA diving. Square $(2 \mathrm{~m} \times 2 \mathrm{~m}$ ) quadrats (for SW, PP, HP and ScW), and $1 \mathrm{~m} \times 4 \mathrm{~m}$ rectangles (for $\mathrm{SZ}$ ) were placed on the substrate. Feeding use was recorded as individual bites within the quadrats. Bites and size of each individual of the 3 species were recorded over 15 min intervals. We counted 3 quadrats per habitat, and 3 replicates per quadrat. To test differences in feeding rate between habitats, individual 1-way ANOVA were performed for each fish species. When the analysis of variance showed significant differences, a Tukey HSD test was used.

To determine feeding habits of the 3 species, fish were speared at several sites within the Marine Reserve in April, May, August and November 1992, and in February 1993. All collections were made between 7:00 and 11:00 h. This time period yielded the maximum amount of identifiable gut contents, since fish start feeding after sunrise. Fish were conserved in a portable fridge and then transported to the laboratory. Total and gutted mass $(\mathrm{g})$ and total length (mm) were measured for each fish sampled. Stomachs, removed by severing the oesophagus near the buccal cavity and the intestine just anterior to the pyloric caecae, were preserved in a neutral $10 \%$ formalin solution within $4 \mathrm{~h}$ of spearing

Stomach contents were carefully sorted and their contents were quantified following the method described by Harmelin-Vivien (1979). Food items were identified to the lowest possible taxon and then weighed. For each stomach, the cover of each algal taxon (in $\mathrm{cm}^{2}$ ) was determined on a reticulated field, and the relative cover of each algal species calculated. The rate of feeding activity was measured by an activity index (AC), which is the percentage of stomachs containing food with respect to the total number of stomachs examined. The $\mathrm{AC}$ varies from 0 (no feeding activity) to 100 (all individuals with food). Several coefficients were calculated to determine the importance of prey in the diet. The occurrence index $(F)$ is the percentage of non-empty stomachs that contained a particular prey item. Percentages by weight of prey $(W)$ were calculated as the ratio of the weight of a prey category $\left(W_{l}\right)$ to the total weight of the stomach content $\left(W_{\mathrm{T}}\right): W=W_{1} / W_{\mathrm{T}} \times 100$. In order not to overemphasize the importance of occasional large prey, a ranking index $(K)$, modified from Hobson (1974), was computed by multiplying the occurrence index $(F)$ by weight of a prey $(K=F \times W / 100)$.

To test whether algal species were similarly present in the diets of the 3 species of Diplodus, individual ANOVAs were used. Some species of algae were rare, or of marginal importance, in the diet. Therefore we analysed those algal species that represented a mean cover $>1 \%$ for at least one fish species. When the 
analysis of variance showed significant differences, a Tukey HSD for unequal $N$ (Spjotvoll/Stoline) test was used.

Resource use overlaps between the 3 species were calculated on the basis of prey types, habitat distribution and habitat use (feeding use). To assess the degree of overlap in use of food between the 3 species the Schoener's index $(T)$ was used as follows:

$$
T=1-0.5 \sum\left|p x_{t}-p y_{i t}\right|
$$

where $p x_{f i}$ and $p y_{f}$ are the proportions by weight in stomachs of the resource fi (prey category) for all fish species pairs $x, y$. Habitat overlaps from (1) species distribution and (2) habitat (feeding) use were determined as:

$$
\alpha_{H}=1-0.5 \sum\left|p x_{h i}-p y_{h i}\right|
$$

where $p x_{h i}$ and $p y_{h i}$ are (1) the proportions of abundance (from visual census) in the habitat hi for all fish species pairs $x, y$; or (2) the proportions of habitat use (from feeding observations) of the microhabitat hi for all species (or size) pairs $x, y$. These overlap indexes vary from 0 , when the 2 species use totally different resources, to 1 , when they use the same prey categories in the same proportions. An overlap equal to or above 0.6 was considered significant, following Keast (1978)

The distribution of algal species over the 5 habitats was quantitatively studied by means of $25 \mathrm{~cm} \times 25 \mathrm{~cm}$ quadrats, divided in 25 subquadrats of $5 \mathrm{~cm} \times 5 \mathrm{~cm}$. Six quadrats were positioned within each of the 5 habitats. The percentage of subquadrats in which a species appeared was recorded and used as the unit of measure. A highly abundant species that appeared in all 25 subquadrats would produce a presence of $100 \%$, whereas the total lack of a species would produce a presence of $0 \%$. Presence of a species in each habitat was then calculated as the mean of the percentage presence values of the 6 quadrats sampled in the habitat. Field visual methods did not allow identification of the smallest algal species in the Medes Islands, which exhibit a very intrincate complex formed by several species of small filamentous algae. Hence, these species were pooled in a single group, called 'turf algae complex', during visual estimations. Subsequently, a semiquantitative sampling of this complex was carried out for each of the 6 quadrats in each habitat. Each sample was carefully sorted in the laboratory, and all algal species were determined. The presence of a species in a habitat was then calculated as the percentage of quadrats in which this species was present.

In order to correlate the abundance of algae in fish stomach contents with the distribution of algae among the 5 habitats, individual non-parametric correlations on untransformed data were carried out between the abundance (percentage presence) of algae for each habitat and the relative cover of algae found in stomach contents for each fish species. We assume that highest correlation coefficients will indicate the habitat in which fish are eating most.

\section{RESULTS}

All fish species were found within all depth zones, except Diplodus vulgaris, which was not found in the surge zone (Fig. 2). D. sargus was found at higher abundance in the surge zone (average of $389 \mathrm{ind} .150 \mathrm{~m}^{-2}$ ), and its density significantly decreased with depth (1-way ANOVA, $F=50.97, \mathrm{df}=2, \mathrm{p}<0.001$; Tukey HSD test, $p<0.001$ ). The density of $D$. vulgaris significantly increased with depth (1-way ANOVA, $F=$ 4.05, $\mathrm{df}=2, \mathrm{p}<0.05$ ), reaching maximum average densities of 18.7 ind $150 \mathrm{~m}^{-2}$ in the deep zone (Tukey HSD test, $\mathrm{p}<0.05)$. Although more abundant in deep waters ( 4.1 ind $150 \mathrm{~m}^{-2}$ ), D. puntazzo did not show significant differences in density between zones (1-way ANOVA, $F=1.97, \mathrm{~d} f=2, \mathrm{p}=0.12$ ). Habitat (spatial distribution) overlap $\left(\alpha_{H}\right)$ was high and significant only between $D$. vulgaris and $D$. puntazzo $\left(\alpha_{H}=0.82\right)$, the other combinations of species pairs returned values $<0.6$.

The 3 species exhibited different uses of the habitats (Fig. 3). Diplodus sargus fed more intensely in the surge zone $\left(\sim 147\right.$ bites $\left.15 \mathrm{~min}^{-1} 4 \mathrm{~m}^{-2}\right)$, and its feeding rate decreased from photophilic to hemisciaphilic to sciaphilic habitats (1-way ANOVA, $F=10.66$, df $=4$, $p<0.001$; Tukey HSD test, $p<0.001$ ). D. vulgaris was not found feeding in the surge zone, and its maximum feeding rate ( 79.4 bites $15 \mathrm{~min}^{-1} 4 \mathrm{~m}^{-2}$ ), in the hemisciaphilic plain, was significantly higher than its feeding rate in the other habitats (1-way ANOVA, $F=4.31$, $\mathrm{df}=4, \mathrm{p}<0.01$; Tukey HSD test, $\mathrm{p}<0.05)$. D. puntazzo

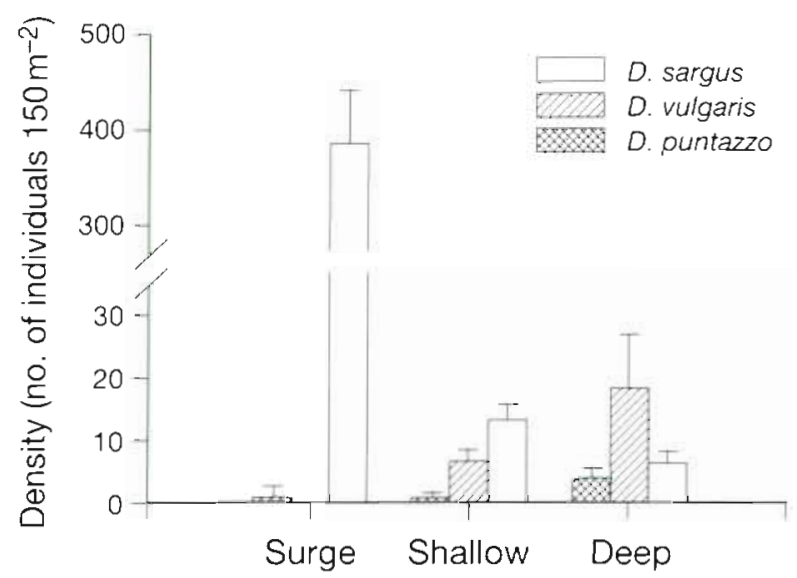

Fig. 2. Diplodus spp. Densities (mean $\pm \mathrm{SE}$ ) of the 3 species at each of the 3 depth-defined zones considered 


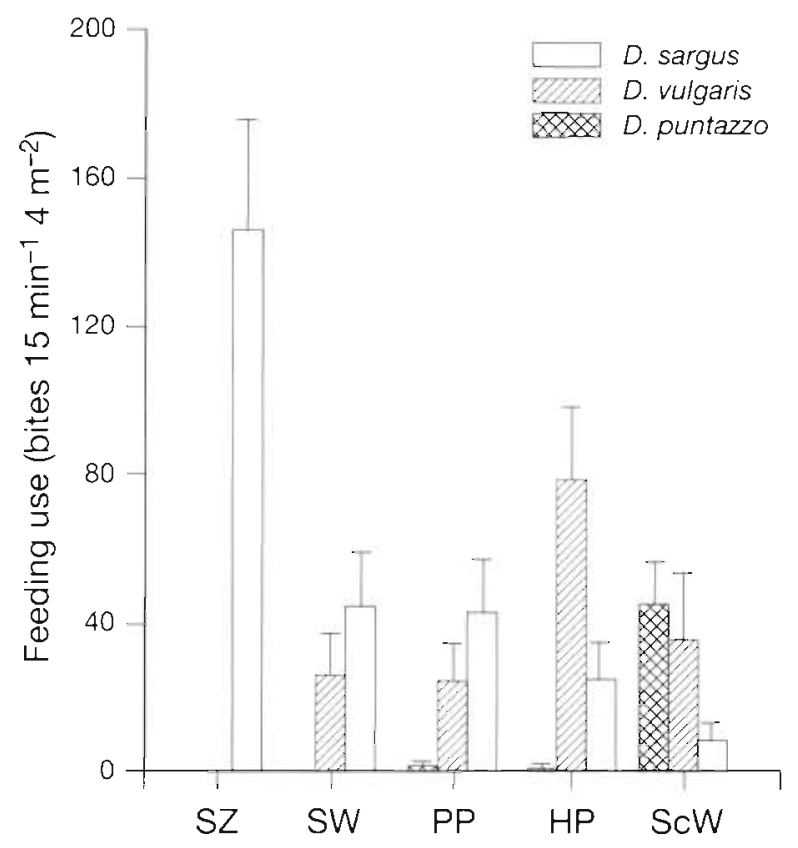

Fig. 3. Diplodus spp. Habitat use (feeding rate; mean $\pm \mathrm{SE}$ ) for the 3 species in the Medes Islands rocky infralittoral. SZ: surge zone; SW: shallow walls; PP: photophilic plaın; HP: hemisciaphilic plain; ScW: sciaphilic walls

was the species with the most restricted feeding: it used only 3 of the 5 habitats investigated in this study (PP, HP and ScW), and its maximum feeding rate was on the sciaphilic walls ( 45.7 bites $15 \mathrm{~min}^{-1} 4 \mathrm{~m}^{-2}$ ), which was significantly higher than its feeding rates in the other habitats (1-way ANOVA, $F=15.54, \mathrm{df}=4, \mathrm{p}<$ 0.001 ; Tukey HSD test, $p<0.001$ ). The use of habitats as a function of size is shown in Fig. 4. D. sargus exhibited an increase in feeding rate for medium and large individuals in SZ, whereas small individuals fed more intensely in SW and PP. Small and medium $D$. vulgaris fed mostly in HP, whereas large individuals fed only in ScW. Medium and large D. puntazzo fed mostly in ScW. We did not find any small $D$. puntazzo.

There was no intraspecific habitat (feeding use) overlap $\left(\alpha_{H}\right)$ for size classes within any species, and there was strong interspecific overlap in only 2 cases:

(1) between small Diplodus sargus and $D$. vulgaris $\left(\alpha_{H}=0,80\right)$, and (2) between medium $D$. puntazzo and large $D$. vulgaris $\left(\alpha_{H}=0.99\right)$.

The diets of 78 individuals of Diplodus sargus were examined, and 69 of these, ranging from 70 to $400 \mathrm{~mm}$ length (mean $=246 \mathrm{~mm}$ ), contained food (Table 2). $D$. sargus was clearly omnivorous, with bivalves (mainly Mytilus galloprovincialis) representing the most important prey type (following ranking index), followed by algae, sea urchins, and barnacles. However, benthic algae were the most frequently found item in the stomachs of $D$. sargus $(F=44 \%)$. Polychaetes, deca-

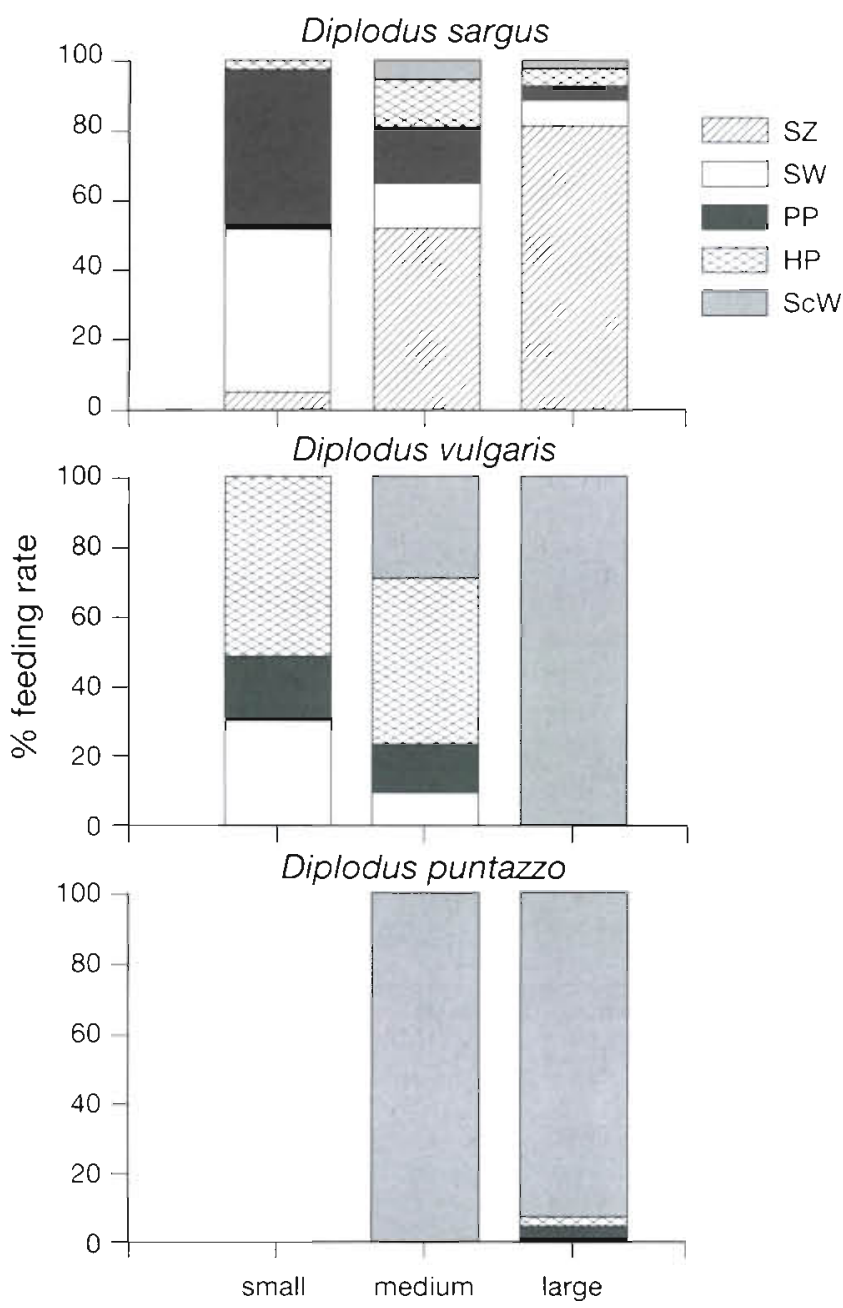

Fig. 4. Diplodus spp. Habitat use as a function of size, expressed as percentage of feeding rate performed by each fish size class at each habitat, for the 3 species. SZ: surge zone; SW: shallow walls; PP: photophilic plain; HP: hemisciaphilic plain; ScW: sciaphilic walls. Small, $<13 \mathrm{~cm}$ (total length); medium, $13-26 \mathrm{~cm}_{i}$ large,$>26 \mathrm{~cm}$

pods and amphipods were also well represented. The ingestion of algae was diverse, with 55 species of algae found in the stomachs. Other organisms were ingested less frequently.

The diets of 47 individuals of Diplodus vulgaris were examined, and 44 , ranging from 100 to $240 \mathrm{~mm}$ (mean $=183 \mathrm{~mm}$ ), contained food (Table 2 ). D. vulgaris may be considered as omnivorous, bivalves representing the most important prey type, followed by ophiures and polychaetes. However, amphipods and benthic algae were frequently found in the stomachs of $D$ vulgaris $(F=59 \%$ and $57 \%$ respectively), in spite of the low amount in stomachs. Other groups like hydroids and sea urchins were also abundant, but low by ranking index, relative to percentage total biomass. Stolons from hydroids were also frequently found in stomach contents 
Table 2. Overall food and feeding habits of 3 Diplodus species inhabiting rocky infralittoral bottoms in the Medes Islands. $\mathrm{AC}$ : \% stomachs containing food; $F$ : \% occurrence frequency of prey; $W$ : \% prey weight; $K$ : ranking index $+:<0.1$

\begin{tabular}{|c|c|c|c|c|c|c|c|c|c|}
\hline & \multicolumn{3}{|c|}{ Diplodus sargus } & \multicolumn{3}{|c|}{ Diplodus vulgaris } & \multicolumn{3}{|c|}{ Diplodus puntazzo } \\
\hline No. of ind examined & & 78 & & & 47 & & & 16 & \\
\hline No. of ind with full stom & & 69 & & & 44 & & & 16 & \\
\hline $\mathrm{AC}$ & & 88.5 & & & 93.6 & & & 100 & \\
\hline \multirow[t]{2}{*}{ Length range (mm) } & & $70-400$ & & & $100-24$ & & & $285-36$ & \\
\hline & $F$ & $W$ & $K$ & $F$ & $W$ & $K$ & $F$ & $w$ & $K$ \\
\hline Algae & 4.3 .5 & 10.4 & 4.5 & 56.8 & 3.8 & 2.2 & 100 & 21.9 & 21.9 \\
\hline Seagrasses & 8.7 & 0.9 & 0.1 & 5.0 & 0.1 & + & - & - & - \\
\hline Sponges & - & - & - & - & - & - & 81.2 & 23.1 & 18.8 \\
\hline Hydroids & 14.5 & 0.1 & + & 34.1 & 0.8 & 0.3 & 81.2 & 7.7 & 6.3 \\
\hline Anthozoans & - & - & - & 2.3 & 0.1 & + & 37.5 & 19.7 & 7.4 \\
\hline Sipunculids & - & - & - & 2.3 & 0.4 & + & - & - & - \\
\hline Polyplacophores & 1.4 & 0.2 & + & 9.1 & 0.7 & 0.1 & - & - & - \\
\hline Gastropods & 4.3 & 0.5 & + & 6.8 & 0.2 & + & - & - & - \\
\hline Opistobranchs & - & - & - & 2.3 & + & + & 18.7 & + & + \\
\hline Bivalves & 37.7 & 57.5 & 21.7 & 40.9 & 51.8 & 21.2 & 62.5 & 4.0 & 2.5 \\
\hline Polychaetes & 18.8 & 0.9 & 0.2 & 38.6 & 8.2 & 3.2 & 43.8 & 2.7 & 1.2 \\
\hline Harpacticoid copepods & 1.4 & + & + & 11.4 & 0.2 & + & 6.2 & + & + \\
\hline Barnacles & 27.5 & 5.0 & 1.4 & - & - & - & 25.0 & 0.8 & 0.2 \\
\hline Decapods & 17.4 & 1.3 & 0.2 & 13.6 & 1.8 & 0.2 & 6.2 & + & + \\
\hline Cumaceans & 1.4 & + & + & - & - & - & - & - & - \\
\hline Tanaids & 1.4 & + & + & 2.3 & + & + & 6.2 & + & + \\
\hline Isopods & 2.9 & + & + & 36.4 & 0.1 & + & - & - & - \\
\hline Amphipods & 36.2 & 0.6 & 0.2 & 59.1 & 3.6 & 2.1 & 62.5 & 0.3 & 0.2 \\
\hline Pycnogonids & 1.4 & + & + & 4.5 & 0.1 & + & 18.8 & + & + \\
\hline Bryozoans & 4.3 & + & + & 4.5 & 0.1 & + & 50.0 & 0.1 & + \\
\hline Holothurians & 1.4 & + & + & - & - & - & - & - & - \\
\hline Echinids & 13.0 & 19.4 & 2.5 & 34.1 & 1.7 & 0.6 & - & - & - \\
\hline Asteroids & - & - & - & 2.3 & 0.2 & + & - & - & - \\
\hline Ophiures & 2.9 & + & + & 36.4 & 14.1 & 5.1 & 56.2 & 0.3 & 0.2 \\
\hline Ascidians & 2.9 & 0.5 & + & 2.3 & + & + & 18.8 & 0.2 & + \\
\hline Rock fragments & - & - & - & 6.8 & 0.4 & + & - & - & - \\
\hline Unidentified fragments & 39.1 & 2.5 & 1.0 & 79.6 & 11.3 & 9.0 & 100 & 19.0 & 19.0 \\
\hline
\end{tabular}

Sixteen individuals of Diplodus puntazzo were examined and all individuals, ranging from 285 to $365 \mathrm{~mm}$ length (mean $=336 \mathrm{~mm}$ ), were found to contain food (Table 2). D. puntazzo was markedly omnivorous, algae representing the most important prey type, followed by sponges (18 species) and cnidarians. These groups accounted for $72 \%$ of the weight of total stomach contents. Algae were found in all stomachs examined, and sponges in $81 \%$ of stomachs.

The overall feeding niche overlap ( $T$ ) was high and significant only between Diplodus sargus and $D$. vulgaris $(T=0.69)$, but was low between the other species pairs.

Although the 3 fish species consumed large numbers of common species of algae, there were differences in the amounts of the species consumed (Table 3). The most abundant algae ingested by Diplodus sargus were, in decreasing order of abundance, Gelidium pusillum, Corallina elongata, Ulva rigida, and Osmundea truncata. For D. vulgaris, algal species were Falkenbergia rufolanosa, undetermined. Bryopsidales, Plocamium cartilagineum, and Cladophora spp. D. puntazzo ingested preferentially Flabellia petiolata, $P$. cartilagineum, Rhodymenia ardissonei, and undetermined Bryopsidales.

The 3 fish species showed distinct algal feeding habits (Table 3). The Tukey HSD test showed that the algae Ulva rigida, Gelidium pusillum, and Osmundea truncata were primarily consumed by Diplodus sargus. Flabellia petiolata, Lomentaria ercegovicii, Rhodymenia ardissonei, and Peyssonnelia spp. were primarily consumed by $D$. puntazzo. However, $D$. vulgaris did not exhibit a clear pattern of algal ingestion. The Tukey test showed no significant differences between $D$. vulgaris and D. puntazzo for Plocamium cartilagineum, Falkenbergia rufolanosa, Halopteris filicina, Dictyota dichotoma, undetermined Bryopsidales, and Rhodophyllis divaricata. The overall niche overlap in algae feeding was low $(T<0.6)$ and thus we might conclude that there was no overlap between Diplodus species.

The distribution of algae in the 5 habitats is shown in Table 4. Several macroal.gal species were common to all habitats, but certain characteristic species were found only in one particular habitat. The turf algae 
Table 3. Relative cover $( \pm \mathrm{SE}$ ) of algae found in stomachs of 3 Diplodus species in the Medes Islands. Algal taxa with an average abundance $<1 \%$ for all fish species were not included in the analysis. Significance level from individual ANOVA. NS: non significant, $p<0.05, \cdots p<0.01, \cdots p<0.001$

\begin{tabular}{|c|c|c|c|c|}
\hline & D. sargus & D. vulgaris & D. puntazzo & p-level \\
\hline $\begin{array}{l}\text { Length range (mm) of ind. } \\
\text { with stomachs containing algae }\end{array}$ & $180-365$ & $170-240$ & $285-365$ & \\
\hline Acrosorium venulosum & $0.00 \pm 0.00$ & $0.00 \pm 0.00$ & $1.32 \pm 1.32$ & NS \\
\hline Aphanocladia stichidiosa & $0.53 \pm 0.31$ & $4.54 \pm 3.14$ & $0.94 \pm 0.64$ & NS \\
\hline Bryopsidales undetermined & $0.00 \pm 0.00$ & $13.94 \pm 6.02$ & $7.73 \pm 4.15$ & $\cdot$ \\
\hline Bryopsis duplex & $1.01 \pm 0.60$ & $0.00 \pm 0.00$ & $0.62 \pm 0.62$ & NS \\
\hline Bryopsis sp. plur. & $0.69 \pm 0.69$ & $3.49 \pm 3.49$ & $0.06 \pm 0.06$ & NS \\
\hline Ceramium rubrum & $0.00 \pm 0.00$ & $1.82 \pm 1.82$ & $0.00 \pm 0.00$ & NS \\
\hline Champia parvula & $2.87 \pm 2.87$ & $1.51 \pm 1.51$ & $0.00 \pm 0.00$ & NS \\
\hline Cladophora pellucida & $2.10 \pm 1.55$ & $0.00 \pm 0.00$ & $0.00 \pm 0.00$ & NS \\
\hline Cladophora prolifera & $0.00 \pm 0.00$ & $0.00 \pm 0.00$ & $2.06 \pm 2.06$ & NS \\
\hline Cladophora sp. plur. & $1.24 \pm 0.87$ & $9.79 \pm 6.26$ & $0.06 \pm 0.06$ & NS \\
\hline Codium vermilara & $7.80 \pm 4.22$ & $0.00 \pm 0.00$ & $0.11 \pm 0.11$ & NS \\
\hline Corallina elongata & $10.40 \pm 4.74$ & $4.54 \pm 4.54$ & $2.78+1.89$ & NS \\
\hline Cryptonemia lomation & $0.00 \pm 0.00$ & $0.00 \pm 0.00$ & $2.41 \pm 2.41$ & NS \\
\hline Delesseriaceae undetermined & $0.00 \pm 0.00$ & $3.57 \pm 2.56$ & $0.00 \pm 0.00$ & NS \\
\hline Dictyota dichotoma & $0.00 \pm 0.00$ & $2.27 \pm 2.27$ & $0.90 \pm 0.42$ & $\cdots$ \\
\hline Falkenbergia rufolanosa stadium & $1.27 \pm 0.94$ & $21.90 \pm 7.90$ & $1.82 \pm 1.09$ & $\cdot$ \\
\hline Flabellia petiolata & $0.00 \pm 0.00$ & $0.00 \pm 0.00$ & $20.83 \pm 8.06$ & $\cdots$ \\
\hline Gelidium pusillum & $11.63 \pm 4.89$ & $0.00 \pm 0.00$ & $0.58 \pm 0.58$ & $\cdot$ \\
\hline Halimeda tuna & $2.41 \pm 2.16$ & $0.00 \pm 0.00$ & $0.00 \pm 0.00$ & NS \\
\hline Halopteris filicina & $0.00 \pm 0.00$ & $2.27 \pm 2.27$ & $4.81 \pm 2.99$ & $\cdots$ \\
\hline Jania rubens & $0.80 \pm 0.59$ & $0.00 \pm 0.00$ & $2.53 \pm 2.53$ & NS \\
\hline Osmundea truncata & $8.17 \pm 4.18$ & $0.00 \pm 0.00$ & $0.00 \pm 0.00$ & $\cdot$ \\
\hline Lomentaria clavellosa & $0.90 \pm 0.52$ & $0.00 \pm 0.00$ & $2.02 \pm 1.16$ & NS \\
\hline Lomentaria ercegovicii & $0.00 \pm 0.00$ & $0.00 \pm 0.00$ & $2.02 \pm 1.24$ & -. \\
\hline Peyssonnelia sp. & $0.00 \pm 0.00$ & $1.52 \pm 1.52$ & $2.03 \pm 1.31$ & $\cdots$ \\
\hline Plocamium cartilagineum & $2.17 \pm 1.74$ & $12.00 \pm 5.20$ & $19.17 \pm 5.16$ & $\cdots$ \\
\hline Polysiphonia spp. & $5.24 \pm 3.67$ & $1.14 \pm 0.83$ & $1.00 \pm 0.68$ & NS \\
\hline Porphyra leucosticta & $1.61 \pm 1.41$ & $0.00 \pm 0.00$ & $0.00 \pm 0.00$ & NS \\
\hline Porphyra umbilicalis & $1.69 \pm 1.28$ & $0.00 \pm 0.00$ & $0.00 \pm 0.00$ & NS \\
\hline Rhodophyllis divaricata & $0.04 \pm 0.04$ & $2.27 \pm 2.27$ & $5.61 \pm 4.14$ & $\cdot$ \\
\hline Rhodymenia ardissonei & $1.81 \pm 1.34$ & $1.51 \pm 1.51$ & $8.43 \pm 3.71$ & .. \\
\hline Schottera nicaeensis & $4.90 \pm 3.54$ & $0.00 \pm 0.00$ & $0.00 \pm 0.00$ & NS \\
\hline Sphacelaria cirrosa & $0.09 \pm 0.09$ & $6.81 \pm 4.98$ & $1.07 \pm 0.64$ & NS \\
\hline Sphaerococcus coronopifolius & $0.00 \pm 0.00$ & $1.52 \pm 1.52$ & $0.99 \pm 0.99$ & NS \\
\hline Ulva rigida & $9.56 \pm 4.15$ & $0.00 \pm 0.00$ & $0.00 \pm 0.00$ & $\cdots$ \\
\hline Valonia utricularis & $1.36 \pm 1.36$ & $0.00 \pm 0.00$ & $0.00 \pm 0.00$ & NS \\
\hline
\end{tabular}

complex was abundant in all habitats. Likewise, some turf algae species were frequently found in all habitats, but some species exhibited differential distributions among habitats. If we consider the algae that indicated trophic segregation between the 3 species of Diplodus (Table 3), the patterns of distribution were the following. Some species exhibited wide distribution patterns. Falkenbergia rufolanosa was highly abundant in the turf algae complex within all habitats, though large plants were only found in the shallow habitats (SZ, SW and PP). Plocamium cartilagineum was also found in the turf algae complex of all habitats - principally in HP and ScW-although large plants were only found in the SW. Halopteris filicina was present in HP and ScW. The undetermined Bryopsidales and Rhodophyllis divaricata were present in the turf algae complex of all habitats. The Peyssonnelia species were found in most habitats, but only 2 species were present in shallow habitats, whereas 5 species were found in ScW. Dictyota dichotoma was found in 4 habitats, but mainly in PP and HP. Some other algal species exhibited narrow patterns of distribution. Flabellia petiolata was only found in the deep habitats, and chiefly in ScW. Lomentaria ercegovicii was present in the turf algae complex of PP and ScW. Rhodymenia ardissonei was most abundant in ScW. Gelidium pusillum was only found in the SZ and SW habitats. Ulva rigida and Osmundea truncata were only found in the SZ habitat.

Correlations between fish stomach contents and habitats are shown in Table 5. The algae found in Diplodus sargus were significantly and positively correlated with algae of SZ. D. vulgaris algal diet was 
Table 4. Percentage presence of algae $( \pm \mathrm{SE}$ ) in the 5 habitats investigated in the rocky infralittoral in the Medes Islands. SZ: surge zone; SW: shallow walls; PP: photophilic plain; ScW: sciaphilic walls; HP: hemisciaphilic plain

\begin{tabular}{|c|c|c|c|c|c|}
\hline & $\mathrm{SZ}$ & SW & PP & ScW & $\mathrm{HP}$ \\
\hline Bryopsis muscosa & $2.0 \pm 2.0$ & & & & \\
\hline Callithamnion granulatum & $7.1 \pm 1.1$ & & & & \\
\hline Callithamnion tetragonum & $6.2 \pm 2.2$ & & & & \\
\hline Ceramium ciliatum & $22.4 \pm 7.1$ & & & & \\
\hline Ceramium diaphanum & $16.7 \pm 5.1$ & & & & \\
\hline Ceramium rubrum & $44.3 \pm 9.0$ & & & & \\
\hline Cladophora laetevirens & $35.5 \pm 15.2$ & & & & \\
\hline Cystoseira mediterranea & $7.0 \pm 3.5$ & & & & \\
\hline Enteromorpha compressa & $3.3 \pm 3.3$ & & & & \\
\hline Grateloupia filicina & $2.0 \pm 2.0$ & & & & \\
\hline Osmundea trunedta & $11.2 \pm 3.6$ & & & & \\
\hline Porphyra leucosticta & $2.0 \pm 2.0$ & & & & \\
\hline Scytosiphon lomentaria & $4.4 \pm 4.4$ & & & & \\
\hline Ulva rigida & $33.3 \pm 13.0$ & & & & \\
\hline Aglaozonia melanoidea stadium & & $14.0 \pm 8.1$ & & & \\
\hline Amphiroa rigida & & $0.7 \pm 0.7$ & $1.3 \pm 1.3$ & & $6.7 \pm 3.8$ \\
\hline Asparagopsis armata & $4.3 \pm 2.3$ & $6.7 \pm 6.7$ & & & \\
\hline Bryopsidales undetermined & & $8.0 \pm 8.0$ & $2.7 \pm 2.7$ & $8.0 \pm 4.5$ & \\
\hline Cladophora pellucida & & $38.7 \pm 8.9$ & & & \\
\hline Colpomenia sinuosa & & $5.3 \pm 3.2$ & $1.3 \pm 1.3$ & & \\
\hline Corallina elongata & $95.0 \pm 4.4$ & $29.3 \pm 15.7$ & $72.7 \pm 12.8$ & & $38.7 \pm 12.4$ \\
\hline Dictyota dichotoma & $2.5 \pm 2.5$ & $2.7 \pm 2.0$ & $32.0 \pm 9.8$ & & $33.3 \pm 7.3$ \\
\hline Dictyota fasciola & & $6.0 \pm 1.7$ & $6.7 \pm 2.7$ & & \\
\hline Falkenbergia rufolanosa stadium & $2.5 \pm 2.5$ & $51.3 \pm 14.4$ & $16.7 \pm 8.9$ & & \\
\hline Gastroclonium clavatum & $7.5 \pm 2.5$ & $2.7 \pm 2.0$ & $1.3 \pm 1.3$ & & \\
\hline Gelidium pusillum & $10.0 \pm 3.3$ & $38.7 \pm 12.0$ & & & \\
\hline Gigartina acicularis & $6.0 \pm 3.0$ & $3.3 \pm 2.2$ & $1.3 \pm 1.3$ & & $1.3 \pm 1.3$ \\
\hline Lomentaria clavellosa & & $2.0 \pm 2.0$ & & & \\
\hline Lyngbya sp. & & $6.7 \pm 2.2$ & & & \\
\hline Melobesiae unidentified & & $80.0 \pm 10.0$ & & & \\
\hline Peyssonnelia dubyi & & $17.3 \pm 6.7$ & & & \\
\hline Plocamium cartilagineum & & $4.7 \pm 3.3$ & & & \\
\hline Pseudochlorodesmis furcellata & & $8.7 \pm 5.5$ & & & $1.3 \pm 1.3$ \\
\hline Turf Algae Complex & & $57.3 \pm 10.6$ & $88.7 \pm 3.3$ & $72.0 \pm 8.7$ & $91.3 \pm 4.4$ \\
\hline Valonia utricularis & & $1.3 \pm 1.3$ & $2.7 \pm 2.7$ & & \\
\hline Aglaozonia sp. & & & $18.7 \pm 8.0$ & & \\
\hline Cladophora hutchinsiae & & & $0.7 \pm 0.7$ & & \\
\hline Codium vermilara & & & $2.7 \pm 1.7$ & & $9.3 \pm 4.2$ \\
\hline Corallina granifera & & & $10.7 \pm 5.4$ & & $13.3 \pm 13.3$ \\
\hline Cystoseira compressa & & & $1.3 \pm 1.3$ & & \\
\hline Halopteris scoparia & & & $8.0 \pm 6.5$ & & $26.7 \pm 10.1$ \\
\hline Laurencia cf obtusa & & & $20.7 \pm 11.2$ & & \\
\hline Lithophyllum incrustans & & & $43.2 \pm 12.4$ & & $53.2 \pm 6.5$ \\
\hline Mesophyllum lichenoides & & & $36.7 \pm 14.2$ & $82.0 \pm 5.1$ & $27.3 \pm 7.9$ \\
\hline Padina pavonica & & & $13.3 \pm 9.1$ & & $17.3 \pm 8.8$ \\
\hline Peyssonnelia squamaria & & & $20.7 \pm 8.5$ & $0.7 \pm 0.7$ & $18.0 \pm 10.2$ \\
\hline Acrosorium venulosum & & & & $8.7 \pm 5.5$ & \\
\hline Botryocladia boergesenii & & & & $1.3 \pm 1.3$ & \\
\hline Cryptonemia lomation & & & & $3.3 \pm 2.2$ & $1.3 \pm 1.3$ \\
\hline Flabellia petiolata & & & & $6.3 .3 \pm 8.9$ & $12.0 \pm 7.9$ \\
\hline Gloiocladia furcata & & & & $2.0 \pm 2.0$ & \\
\hline Halimeda tuna & & & & $4.7+3.9$ & $0.7 \pm 0.7$ \\
\hline Halopteris filicina & & & & $6.0 \pm 2.9$ & $18.7 \pm 7.1$ \\
\hline Lithophyllum expansum & & & & $4.7 \pm 2.2$ & \\
\hline Peyssonnelia bornetii & & & & $4.7 \pm 3.0$ & \\
\hline Peyssonnelia harveyana & & & & $2.0 \pm 2.0$ & \\
\hline Peyssonnelia rosa-marina & & & & $1.3 \pm 1.3$ & $2.0 \pm 2.0$ \\
\hline Peyssonnelia rubra & & & & $46.0 \pm 9.0$ & \\
\hline Rhodymenia ardissonei & & & & $2.0 \pm 2.0$ & \\
\hline Aglaozonia parvula stadium & & & & & $15.3 \pm 8.0$ \\
\hline Amphiroa cryptarthrodia & & & & & $8.0 \pm 3.7$ \\
\hline Codium bursa & & & & & $6.0 \pm 4.6$ \\
\hline Cystoseira of. spinosa & & & & & $35.2 \pm 8.2$ \\
\hline Eupogodon spinellus & & & & & $1.3 \pm 1.3$ \\
\hline Gelidium latifolium & & & & & $27 \pm 2.7$ \\
\hline Jania cf. longiarthra & & & & & $2.7 \pm 2.0$ \\
\hline Sphaerococcus coronopifolius & & & & & $2.0 \pm 2.0$ \\
\hline Wrangelia penicillata & & & & & $2.0 \pm 2.0$ \\
\hline
\end{tabular}


Table 5. Diplodus spp. Spearman correlation coefficients among algal abundance in fish stomach contents and in the 5 habitats. SZ: surge zone; SW: shallow walls; PP: photophilic plain; HP: hemisciaphilic plain; ScW: sciaphilic walls. NS: non significant; $\cdot p<0.05, \cdots p<0.01, \cdots p<0.001$

\begin{tabular}{|lccccc|}
\hline & $\mathrm{SZ}$ & $\mathrm{SW}$ & $\mathrm{PP}$ & $\mathrm{HP}$ & $\mathrm{ScW}$ \\
\hline D. sargus & $0.55^{\circ}$ & $0.03^{\mathrm{NS}}$ & $-0.20^{\mathrm{NS}}$ & $-0.27^{\mathrm{NS}}$ & $-0.40^{\mathrm{NS}}$ \\
D. vulgaris & $-0.21^{\mathrm{NS}}$ & $0.62^{\circ}$ & $0.76^{\cdots}$ & $0.81^{\cdots}$ & $0.55^{*}$ \\
D. puntazzo & $-0.62^{\circ}$ & $0.23^{\mathrm{NS}}$ & $0.46^{\mathrm{NS}}$ & $0.69^{\cdots}$ & $0.80^{\cdots}$ \\
\hline
\end{tabular}

significantly and positively correlated with algae for all habitats, except SZ, and highest correlation coefficients were found for PP and HP. The algae found in D. puntazzo were positively and significantly correlated with algae found in HP and ScW, and significantly and negatively correlated with algae from SZ.

\section{DISCUSSION}

Consideration of both distributions and food habits indicates clear differences in resource use among the 3 Diplodus species, although they may overlap in some cases. Although the results of the stomach content analysis showed a significant feeding overlap between $D$. sargus and $D$. vulgaris, we suggest that they may not be sharing resources with each other, because the trophic activities of the 2 species are segregated by differences in habitat use. As observational studies and correlation analysis indicate, $D$. sargus mainly exploited the surge zone, whereas $D$. vulgaris fed more frequently in the hemisciaphilic plain. The spatial distributions of these 2 species also suggests a negative relationship between their activity range. Moreover, $D$. vulgaris was not present in the surge zone, and thus may not present a substantial drain on the food resources it shares with $D$. sargus. However, there may be an interaction between small individuals of both species in the shallow zone, since they exhibited a significant habitat overlap. Nevertheless, the availability of the same kind and different kinds of prey in very close habitats may allow the coexistence of both species, in spite of much higher overall abundance of $D$. sargus. The 'niche complementarity' hypothesis implies that co-occuring species that show a high degree of overlap in one niche dimension (e.g. diet) separate out along another dimension (habitat) (Ebeling \& Hixon 1991). Furthermore, as each species partitioned resources among size classes, both species may coexist in very high numbers within a relatively small habitat.

On sciaphilic walls there was another case of niche complementarity. Density of Diplodus vulgaris was higher than $D$. puntazzo density in deep waters, while feeding use of sciaphilic walls was almost the same for both species. Results from observational studies suggest that there was a high and significant habitat overlap between the 2 species, especially between medium-sized $D$. puntazzo and large-sized $D$. vulgaris. However, the stomach content analysis showed that these 2 species exploit different food resources. Therefore, the 2 species displayed a high degree of overlap in the spatial dimension but separated out along the diet dimension.

Of special interest concerning the segregation in food resource use was the substantial consumption of sponges by Diplodus puntazzo. This species exploited a resource that is apparently not used by any other species of littoral fish in the western Mediterranean, although sponges are an important prey item for some coral-reef fishes (Dunlap \& Pawlik 1996). Exploitation of sponges may segregate $D$. puntazzo ecologically from the other Diplodus species and thereby may help to minimize whatever level of competition for food resources may occur between them.

Ross (1986) suggested that among marine fish assemblages trophic segregation plays a more important role than habitat separation, but this hypothesis is highly controversial, since several other authors found that habitat separation may be as important as trophic segregation in structuring fish assemblages lamong others, Gladfelter \& Johnson 1983, BouchonNavaro 1986, Harmelin-Vivien et al. 1989). Furthermore, Schoener (1974) pointed out that habitat separation is far more effective than food separation in preventing species overlap, although it is more frequent in terrestrial than in aquatic systems. In this study, habitat partitioning appeared as important as food partitioning in structuring fish assemblages.

We recognize that our study is limited in several significant ways. We considered only 3 species - although 2 of them are by far the most abundant species in the habitat studied - at one local site. We did not investigate seasonal trends in resource partitioning, because of the insufficient number of fish caught in some seasons. We examined only habitat-trophic use relationships, and did not evaluate competitive relationships between these species. Observational and diet studies are not appropriate for properly establishing the existence of competition (Connell 1983, Hastings 1987), and therefore experimental studies are needed to ascertain whether the patterns observed are a result of competition between species. We suggest that effort should be focused on the relationship between $D$. sargus and $D$. vulgaris, since $D$. puntazzo already exhibits morphological differences: it has a longer intestine than either of the other 2 species, and thus it appears to be adapted to feeding on 'low-digestible' organisms, like algae and sponges (Sala 1996). 
In this study, visual census of habitat use patterns was combined with gut content analysis and the spatial distribution of algae among habitat types. The combined data provided a very convincing argument that the 3 species partition space and food resources. Although observational study may be carried out easily and relatively quickly, and provides a clear assessment of the use of habitats by fishes, the use of both methods (gut content analysis and visual census) jointly provides more reliable data. The use of a single method might have led to mistaken conclusions concerning resource partitioning. Conversely, it appears that algal stomach contents provide good estimates of habitat use for omnivorous fish in the Mediterranean rocky infralittoral.

Acknowledgements. We are grateful to C. F. Boudouresque and $M$. Zabala for providiny advice and encouragement throughout this study. Thanks to our friends and colleagues $A$. García-Rubies, J. Garrabou, D. Gelada, A. León, J. M. Llenas, M. Llenas, E. Sala Sr and M. Zabala, who collaborated in fish collections. We are indebted to $M$. Harmelin-Vivien, E. Macpherson and $X$. Turón, along with anonymous reviewers, for valuable comments and suggestions. Thanks to L. Polo and the Laboratori de Biologia Vegetal of the Universitat de Girona for laboratory facilities, and to the 'Direcció General de Pesca Maritima de la Generalitat de Catalunya' for field work permission. This research was supported by a 'Diputació de Girona' predoctoral grant to E.S., and by project number PCC $68003 / 9$ of the 'Direcció General de Pesca' of the 'Generalitat de Catalunya'

\section{LITERATURE CITED}

Ballesteros E (1992) Els vegetals i la zonació litoral: espècies, comunitats i factors que influeixen en la seva distribució. Arxius de la Secció de Ciències CI. Institut d'Estudis Catalans, Barcelona

Bauchot ML, Pras A (1980) Guide des poissons marins d'Europe. Delachaux et Niestlé, Lausanne

Bell JD, Harmelin-Vivien ML (1983) Fish fauna of French Mediterranean Posidonia oceanica seagrass meadows. 2Feeding habits. Téthys 11:1-4

Bouchon-Navaro Y (1986) Partitioning of food and space resources by chaetodontid fishes on coral reefs. J Exp Mar Biol Ecol 103:21-40

Coetzee PS (1986) Diet composition and breeding cycle of blacktail, Diplodus sargus capensis (Pisces: Sparidae), caught off St. Croix Island, Algoa Bay, South Africa. S Afr J Zool 21:237-243

Connell JH (1983) On the prevalence and relative importance of interspecific competition: evidence from field experiments. Am Nat 122:661-696

Corbera J, Sabatés A, García-Rubies A (1996). Peces de mar de la Península Ibérica. Planeta, Barcelona

De La Paz R (1975) Systématique et phylogenèse des Sparidae du genre Diplodus Raf., (Pisces, Teleostei). Trav Doc ORSTOM 45

Dunlap M, Pawlik JR (1996) Video-monitored predation by Caribbean reef fishes on an array of mangrove and reef sponges. Mar Biol 126:117-123
Ebeling AW, Hixon MA (1991) Tropical and temperate reef fishes: comparison of community structures. In: Sale PF (ed) The ecology of fishes on coral reefs. Academic Press, San Diego, p 509-563

Ebeling AW, Laur DR (1986) Foraging in surfperches: resource partitioning or individualistic responses? Environ Biol Fish 16:123-133

Feldmann J (1937) Recherches sur la végétation marine de la Méditerranée. Rev Algol 10:73-254

García-Rubies A (1997) Estudi ecològic de les poblacions de peixos litorals sobre substrat rocós a la Mediterrània Occidental: efecte de la fondària, el substrat, l'estacionalitat i la protecció. PhD thesis, Universitat de Barcelona

Gladfelter WB, Johnson WS (1983) Feeding niche separation in a guild of tropical reef fishes (Holocentridae). Ecology 64:552-563

Hallacher LE, Roberts DA (1985) Differential utilization of space and food by the inshore rockfishes (Scorpaenidae: Sebastes) of Carmel Bay, California. Environ Biol Fish 12:91-110

Harmelin JG (1987) Structure et variabilité de l'uchtyofaune d'une zone rocheuse protégée en Méditerranée (Parc National de Port-Cros, France). PSZN I: Mar Ecol 8 263-284

Harmelin-Vivien ML. (1979) Ichtyofaune des récifs coralliens de Tuléar (Madagascar): écologie et relations trophiques Thèse Doct, Université Aix-Marseille II

Harmelin-Vivien $M$, Chauvet $C$, Duval C, Galzin $R$, Lejeune P, Barnabé G, Blanc F, Chevalier R, Duclerc J, Lassere G (1985) Evaluation visuelle des peuplements et populations de poissons. Méthodes et problèmes. Rev Ecol (Terre Vie) 40:467-539 Abraham SS (1989) Food partitioning among scorpaenid fishes in Mediterranean seagrass beds. J Fish Biol 34 $715-734$

Hastings A (1987) Can competition be detected using cooccurrence data? Ecology 68:117-123

Hixon MA (1980) Competitive interactions between California reef fishes of the genus Embiotoca. Ecology 61:918-931

Hobson ES (1974) Feeding relationships of teleostean fishes on coral reefs in Kona, Hawaii. Fish Bull US 72:915-1031

Holbrook SJ, Schmitt RJ (1986) Food acquisition by competing surfperch on a patchy environmental gradient. Environ Biol Fish 16:135-146

Joubert CSW, Hanekom PB (1980) A study of feeding in some inshore reef fish of the Natal Coast, South Africa. S Afr J Zool 15:262-274

Keast A (1978) Trophic and spatial interrelantionships in the fish species of an Ontario temperate lake. Environ Biol Fish $3: 7-31$

Larson RJ (1980) Competition, habitat selection, and the bathymetric segregation of two rockfish (Sebastes) species. Ecol Monogr 50:221-239

Love MS, Ebeling AW (1978) Food and habitat of three switch feeding fishes in the kelp forests off Santa Barbara, California. Fish Bull US 76:257-271

Macpherson E (1981) Resource partitioning in a Mediterranean demersal fish community. Mar Ecol Prog Ser 4 $183-193$

Macpherson E (1994) Substrate utilisation in a Mediterranean littoral fish community. Mar Ecol Prog Ser 114:211-218

Mann BQ, Buxton CD (1992) Diets of Diplodus sargus capensis and Diplodus cervinus hottentotus (Pisces: Sparidae) on the Tsitsikamma coast, South Africa. Koedoe 35:27-36

Pianka ER (1973) The structure of lizard communities. Annu Rev Ecol Syst 21:213-220

Ros J, Olivella I, Gili JM (eds) (1.984) Els sistemes naturals de 
les Illes Medes. Arxius de la Secció de Ciències LXXIll. Institut d'Estudis Catalans, Barcelona

Rosecchi E (1985) Ethologie alimentaire des Sparidae Diplodus annularis, Diplodus sargus, Diplodus vulgaris, Pagellus erythrinus, Sparus aurata du Golfe de Lion et des étangs palavasiens. Thèse doct, Univ Sci Tech Languedoc

Ross ST (1986) Resource partitioning in fish assemblages: a review of field studies. Copeia 1986:352-388

Sala $E$ (1996) The role of fishes in the organization of a Mediterranean sublittoral community. Thèse Doct, Universite Aix-Marseille II

This article was submitted to the editor
Schoener TW (1974) Resource partitioning in natural communities. Science 185:27-39

Tortonese E (1975) Osteichthys pesci ossei. Fauna d'Italia. Vol XI. Calderini, Bologna

Yoshiyama RM (1980) Food habits of three species of rocky intertidal sculpins (Cottidae) in central California. Copeia 1980:515-525

Zander CD (1982) Feeding ecology of littoral gobiid and blennioid fish of the Banyuls area (Mediterranean Sea). 1-Main food and trophic dimension of niche and ecotope. Vie Milieu 32:1-10

Manuscript first received: January 3, 1997

Revised version accepted: April 18, 1997 